\title{
LAND USE CHANGES IN THE ALPINE TREE LINE ECOTONE IN THE HRUBÝ JESENÍK MOUNTAINS (CZECH REPUBLIC)
}

\author{
PETER MACKOVČIN ${ }^{1}$, IVO MACHAR $^{2 *}$, JAN BRUS $^{3}$, BARBORA ŽÁKOVÁ ${ }^{4}$ \\ ${ }^{1-4}$ Faculty of Science, Palacky University, 17 listopadu 12, 77146 Olomouc, \\ Czech Republic \\ *Corresponding authore-mail: ivo.machar@upol.cz
}

Received: $25^{\text {th }}$ June2021, Accepted: $21^{\text {th }}$ September 2021

\begin{abstract}
Currently, we expected a altitudinal shift of forest vegetation upward under predicted climate changes impacts to European mountains ecosystems. In this context can be very interesting, that changes in alpine tree line ecotone in high European mountains were induced by human activities relatively often also in history. Probably one of the most important driver in land-use changes in high mountains was grazing, which significantly have influenced both mountain spruce forests and open alpine grasslands in central-Europe. This paper deals with historical changes of land-use in Hruby Jesenik Mountains (Czech Republic) during $19^{\text {th }}$ and $20^{\text {th }}$ centuries. Results revealed consequences of former grazing in mountain grasslands above alpine tree line ecotone in the frame of land-use analyses based on historical maps and other sources. These results, based on historical data, support our better understanding to current dynamic changes in European mountain landscapes.
\end{abstract}

Keywords: Alpine tree line ecotone, importance of grazing, historical land-use changes, mountain forests.

\section{INTRODUCTION}

At present, a gradual shift of the natural upper tree line to higher altitudes, owing to climatic changes, is being monitored in all the mountain areas of Central Europe (Garamvoelgyi \& Hufnagel, 2013). These climatically conditioned shifts of the upper tree line might, in certain localities, be slowed down as a result of the competition of the Norway spruce (Picea abies) with the Prostrate Dwarf Pine (Pinus mugo), which was unnaturally planted in the $19^{\text {th }}$ and $20^{\text {th }}$ centuries in some European mountain ranges with a view to stabilizing the upper tree line, which had been disturbed by the grazing of farm animals (Šenfelder et al., 2014). In order to understand this complex phenomenon of the mountain areas, it is vitally important to grasp the role of historic human activities in the past, such as the mediaeval colonization of mountains connected with the local intensive exploitation of forests by grazing and litter raking (Šamonil \& Vrška, 2007).

This article deals with the historical changes in the mountain ecosystems of the alpine tree line in Central European mountains. The Alpine tree line ecotone (ATLE) represents a transition zone between mountain forest ecosystems and Alpine grassland ecosystems. The ATLE is considered one of the most important ecological interfaces in mountain landscapes around the world (Treml et al., 2016). The ATLE is formed by trees that often occur in clonal 
Mackovčin P., Machar I., Brus J, Žáková B.: Changes in the alpine tree line ecotone in the Hrubý Jeseník Mountains (Czech Republic)

groups surrounded by prostrate shrubs (Šenfelder \& Maděra, 2011). An important strategy enabling trees to form and maintain stands in environments where seedling growth and survival are limited by cold is vegetative reproduction. Tree line ecotones in western North American mountains contain Abies lasiocarpa, Picea engelmannii, and shrubby Chamaecyparisnootkatensis; those in central Kamchatka include Larix gmelinii and Pinus pumila and those in the Carpathians in Europe have Piceaabies and Juniperus communis ssp. Alpine (Honnay et al., 2004).

The ATLE plays an important role in the provisioning of ecosystem services of montane forests (Kolström, 1998). On a global scale, the most important factor determining the ATLE is temperature (Švajda, 2008). On a regional and local scale, the dynamics of the ATLE and SFBA are determined by a number of specific factors that may often interact (wind pressure, topography, coupled with the dynamics of avalanches and the local distribution of snow, vegetation structure, and anthropogenic activities such as various land use activities. The ATLE in the European mountains has been shaped in the past by grazing, haymaking, and logging. Especially historical grazing is considered as the main driver which induced the downward altitudinal shift of the ATLE in recent centuries. Today, we can recognize an opposite trend - an upward shift of the ATLE, caused by climate change (Garamvoelgyi \& Hufnagel, 2013). These current climate-induced shifts of the ATLE are locally influenced by both natural disturbances and the individual responses of tree species (Macků, 2014).

In order to gain a better understanding of this complicated environmental issue, it is very important to gain knowledge of the history of mountain ecosystems affected by man. The main objective of this paper is to analyse the historical land use changes of the ATLE on the basis of a case study from the Hrubý Jeseník Mountains in the period 1836-2016.

\section{METHODOLOGY AND MATERIAL}

\section{Study area}

The study area is the Praděd National Nature Reserve (NNRP), which is located in the Hrubý Jeseník Mountains (HJM), in the north-eastern part of the Czech Republic (Central Europe). The highest peak in the study area is Praděd - 1491 metres above mean sea level. The surface forms were modelled by mountain glaciers in the glacial period (Demek \& Mackovčin, 2006; Křížek et al., 2005; Treml, 2007). The soils are Cambic Podzols with a high content of skeletal material (Kř́ižek et al., 2008; Kř́ižek et al., 2019). The forests below the ATLE in the NNRP predominantly consist of acidophilous spruce forests and above the ATLE habitats of Alpine grasslands (Chytrý et al., 2010). The total size of the study area is 2,031.4 ha.

Probably the oldest records about vegetation status in the study areas was published by Micklitz (1857). During $20^{\text {th }}$ century, many authors studied alpine vegetation in the study area (Bednář, 1958; Bednáŕ, 1960; Bureš \& Burešová, 1989; Bureš \& Králík, 1977; Hejcman et al., 2006; Hejcman et al., 2010; Jeriová, 1970; Musil, 2010; Neuhäusl \& Neuhäuslová-Novotná, 1966; Novák et al., 2010; Treml \& Banaš, 2000). Special attention has been focused on the forest management related to alpine tree line in the study area (Jeník \& Lokvenc, 1962; Maděra et al., 2011; Sokol, 1965; Treml \& Křížek, 2006; Treml et al., 2016; Wild \& Wildová, 2002; Wild \& Winkler, 2008; Zeidler et al., 2010).

A brief summary of relationships between human activities and natural habitats in the study area published Bureš et al. (2008). The key study of human impacts on alpine habitats in the study area are included in the papers of Bureš et al. (2005), Hošek (1964), and Novák et 
al. (2010). Recently, there were published important studies aimed to tree ecology in the study area (Šenfelder et al., 2016; Šenfelder et al., 2020).

\section{Methodology of land-use changes assessment}

In order to analyse the land-use changes in the area being monitored, four reference years were selected and suitable basic map data for analyses was selected for each year: maps of the stable cadastre of Moravia and Silesia for the reference year 1836, topographic maps of the Czechoslovak Republic (the so-called five-centimetre map) for 1946, a military topographic map of the General Staff of the Czechoslovak Army for 1960, and the Basic Map of the Czech Republic for 2016.

The maps of the stable cadastre of Moravia and Silesia were created between 1826 and 1830 and 1833 and 1836. The objective of this historical mapping during the existence of the Austro-Hungarian Empire was to create cadastral maps for every settlement of the Moravian and Silesian lands on a scale of 1:2880. The maps of this historically stable cadastre provide a detailed view of the land use at that time (Skaloš et al., 2010). Map sheets for the following parts of villages were used for this study: Domašov/Thomasdorf, Kouty nad Desnou/Winkelsdorf, Loučná nad Desnou/Kozianau, Rejhotice/Reitenhau, Rudoltice/Rudelsdorf, Vernířovice/Warmsdorf, Karlov/Karlsdorf, Malá Morávka/Klein Mohrau, Mnichov/Einsiedel, Žd'árský Potok/Brandseifen, and Železná/Buchbergsthal.

The topographic maps of the Czechoslovak Republic (the five-centimetre map) were created in the period between 1934 and 1938 and later 1945 and 1949, with the territory of the Hrubý Jeseník mountains that was monitored being mapped in 1946. The mapping was carried out in what is known as Krovak's projection (a conformal oblique conic projection). The following map sheets were used in this study: 540_1056 Domašov from 1946, 540_1064 Praděd from 1946, and 540_1072 Stará Ves from 1946.

The army topographic maps of the General Staff of the Czechoslovak Army were created between 1957 and 1973 on a scale of 1:10 000. The map for the territory that was monitored was created in 1960, on the basis of a Gauss-Kruger conformal cylindrical projection. The following map sheets were applied for the analysis of the territory that was monitored: M-33-071-C-b-3, M-33-071-C-b-4, M-33-071-C-d-1, M-33-071-C-d-2, M-33-071-C-d-3, M-33-071-C-d-4, M-33-071-D-a-3, and M-33-071-D-c-1.

The Basic Map of the Czech Republic on a scale of 1:10,000 is, at present, the most detailed map on a medium scale projecting the entire territory of the Czech Republic in 2006 and continues to be further updated. The territory that was monitored was, within the framework of this map, updated in 2016.

The above-stated map documents and materials were analysed by means of GIS (geographic information system) tools with the ArcGIS 10.6 software from the ESRI company and all operations were solved within the S-JTSK Krovak East North coordinate system. After the map sheets had been recorded into the software program, each of the sheets was georeferenced. The basic map of the Czech Republic on a scale of 1:10,000 was selected as the base map for georeferencing. At least four photogrammetric points (usually mountaintops or corner points on the border of cadastral territory) were determined for each map sheet. The error indicator for georeferencing, "Tolerance Total RMS Error", ranged between values of 0.3 and 4.9 .

The vectorization of the base documents and materials created line layers for the upper tree line for each reference year.

The upper tree line was, for the purposes of this study, defined as a transition zone between a forest-with-a-closed-canopy ecosystem and an Alpine forest-free-area ecosystem (Treml \& Banaš, 2000). 
The forest below the upper tree line was, for the purposes of this study, defined as growth with a minimum tree coverage of $50 \%$ of the area, the height of the trees being a minimum of $5 \mathrm{~m}$, and with an area of minimum 1 are (Šenfeldr \& Maděra, 2011), whereas the Alpine forest-free area was defined as a negation of the above-stated forest definition.

On the basis of the map documents and materials, the vectorization also created a shapefile point layer of local chalets. These chalets used to serve the purposes of hunters, shepherds, or hikers. Altogether 31 chalets were marked on the territory that was monitored. On the basis of identification in the map documents and materials, it was decided for each of the chalets whether it existed -1 - or did not exist -0 - for the given periods. Some of the chalets (mountain cabins in the past) served as starting points for shepherds and animals that were grazing in the surroundings.

For better orientation in the map outputs, we selected five points, namely Praděd $(1,491$ mamsl), Velká Jezerná (1,248 mamsl), Vysoká hole (1,465 mamsl), Velký Máj (1,386 mamsl), and Malý Klín (1,100 mamsl). These points were marked as a vector point layer based on the WMS ZM 10 map layer. A network of watercourses was selected as another map orientation element.

\section{RESULTS}

\section{Brief review of historical context for land use changes in the territory that was monitored}

In the Hrubý Jeseník mountains, the forests originally belonged to the deep border forest between Moravia and Silesia (Nožička, 1957). From the $12^{\text {th }}$ to the $14^{\text {th }}$ century, the deep forests on the border were divided as a consequence of colonization. The area was distributed to the individual land estates of Branná, Janovice, Loučná, Velké Losiny, Jeseník, Zlaté Hory, and Bruntál (Fig. 1).

Until the 13th century, beech and fir woods used to spread up to the mountain ridges of the Hrubý Jeseník (Nožička, 1957). People started to utilize the massif of the Hrubý Jeseník more intensively only in the 15th and 16th centuries, for the purpose of hunting, wood production, and agriculture. First, the lower areas of the Hrubý Jeseník were used. Land use spread from the deposits of iron ore, i.e. from Zlaté Hory, Jeseník, and Rýmařov. A relatively large amount of wood was needed for iron ore processing, and was, for a long time, obtained by logging in the surrounding areas. Similarly, pasturing was originally carried out especially in the lower parts of the forests. The upper tree line was avoided by man for a long time. As late as in 1750 , local records stated that there was a lot of rotting wood and blown-down trees lying over each other in the area of the Loučná forests below Praděd (Hošek, 1973).

The forests originally spread up to the mountain ridges and forest-free areas were limited to small territories around the highest peaks of Praděd, Vysoká hole, and Keprník. At the end of the $18^{\text {th }}$ century, when the consumption of processed wood grew significantly, selective wood cutting was abandoned and replaced by clear cutting. Clear cutting was used on significantly large areas, which often reached up to the upper tree line, and the clearings were not even properly reforested (Bohn et al., 2002). 
Fig. 1: Division of the deep border forest into individual land estates.

Source: Hošek, 1973.

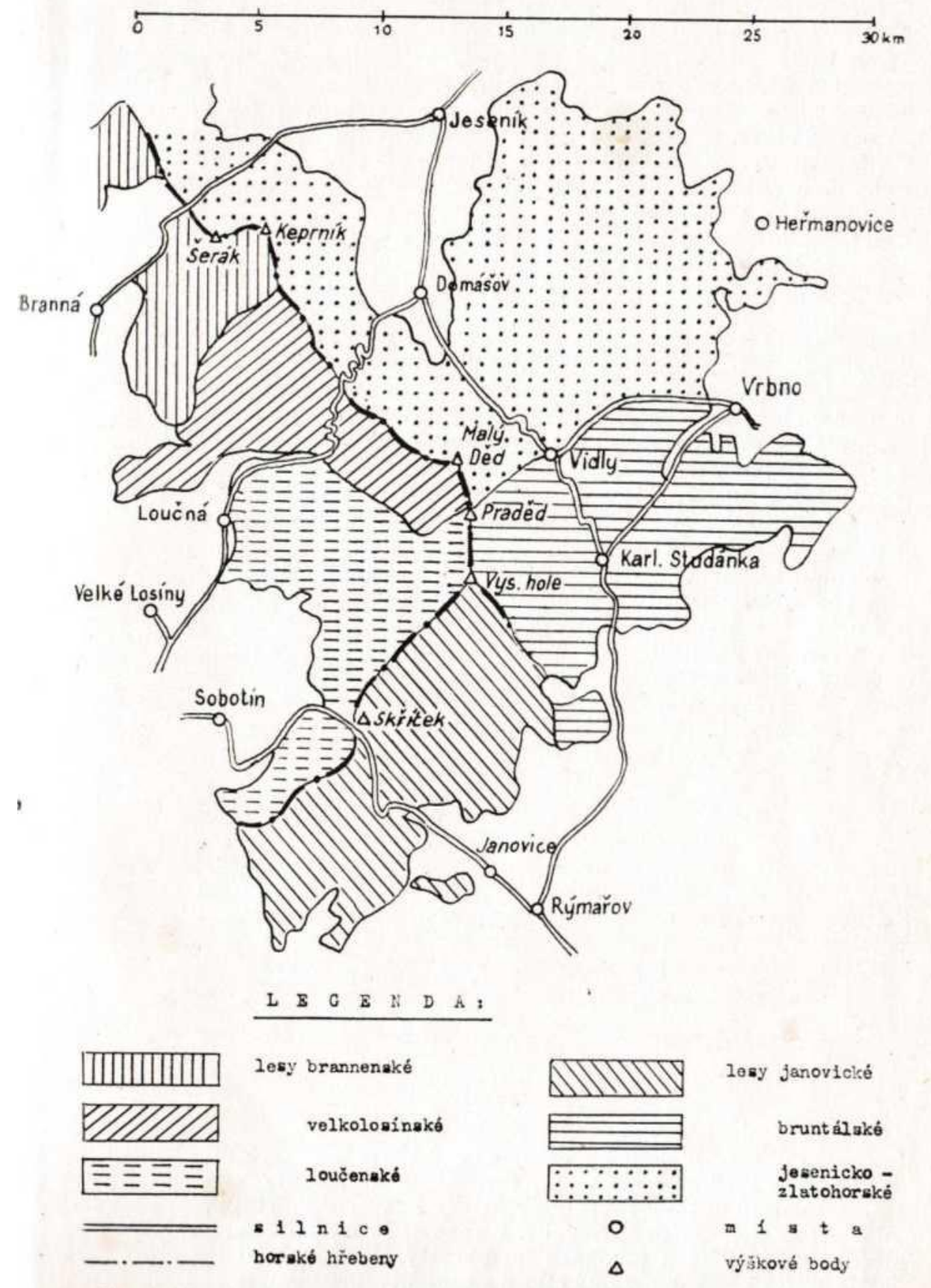


In the 18th century, intensive grazing of sheep and cattle was carried out on the mountain areas that had been cleared after deforestation. Such intensive grazing began to support the extension of cleared mountain areas, especially on the eastern slopes of Praděd (Hošek, 1972). The first recorded mention of the above was in 1736, when a map of the Velke Losiny land estate indicates that there was a Česnek House/Knoblochhaus, which served as a dwelling for shepherds and for the storage of dairy products, located below Malý Děd. Around 1750, the grazing of herds on the cleared mountain areas was already quite regular. In 1829, a new hut was inhabited, located on the original site of the Česnek House. This place began to be called Švýcárna/Schweizerei after the nationality of its inhabitants. Another mountain house, Ovčárna/Schaferei, also boasts a rich history. The house was reconstructed in 1863 and replaced the original building from 1820. It was very well equipped by the standards of the time, because, apart from an animal shelter for sheep, it also featured a flat for the shepherd and rooms for processing milk. Ovčárna soon became a popular destination for hikers and also foresters (Knappe, 1803).

At first, people used to build only modest practical chalets in the highest mountain areas, which were, however, as time went on, extended and reconstructed. 31 mountain chalets were recorded in the territory that was monitored (Table 1). Only three of them were used for housing sheep and cattle - Ovčárna, Švýcárna, and Kurzovní.

The first mentions of the land use in the area and chalets for hiking come from the 1840s. For example, in Švýcárna, hikers could seek shelter from unfavourable weather, get something to eat, or stay overnight. From 1860, Švýcárna's purpose shifted mainly to acting as a shelter for the landlord's huntsmen and as a lodging house for hikers. The Frantiskova forester's lodge, which managed to keep the singular character of its timberwork for a long time, was also used for huntsmen's purposes. In 1887, a new chalet was constructed exclusively for hikers (Hošek, 1970). It is obvious from period photographs that grazing was popular in the surroundings of Švýcárna even in the $20^{\text {th }}$ century. The cattle were housed in a facility close to the chalet (Fig. 2).

\section{Fig. 2: Grazing around Švýcárna in the $20^{\text {th }}$ century}

Source: private archive

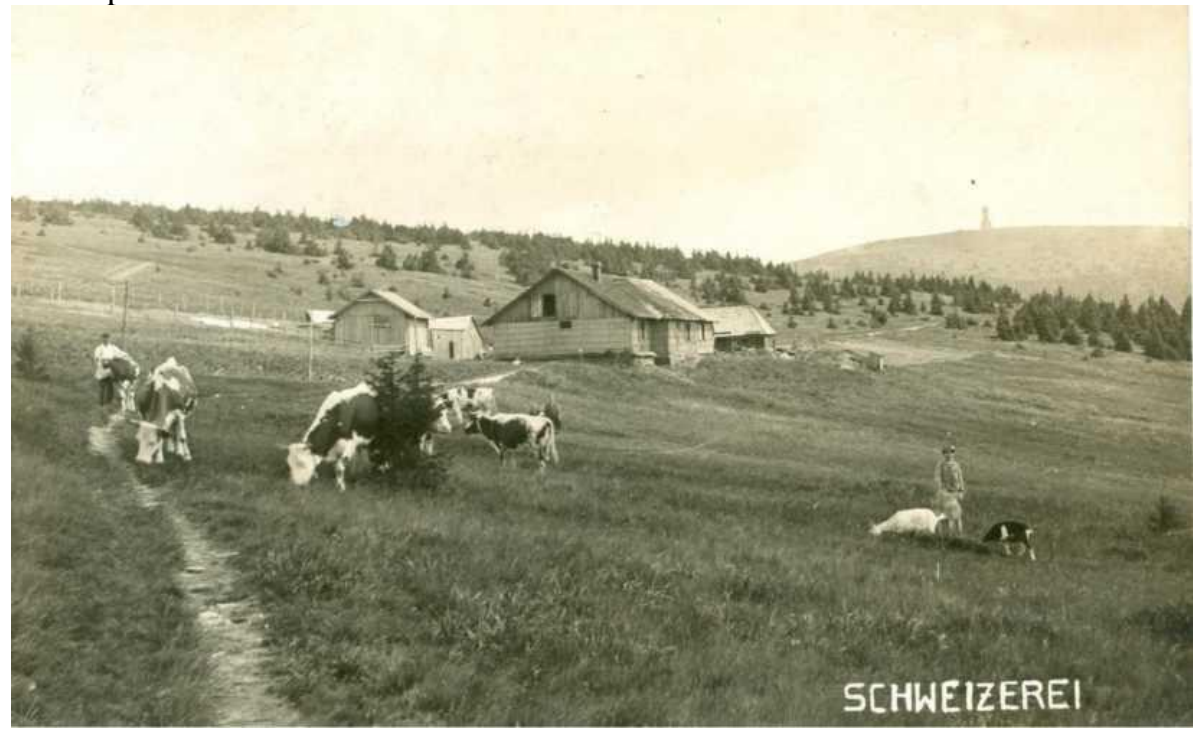


Table 1: Mountain chalets in the selected part of the Praděd highlands1836-2016

\begin{tabular}{|c|c|c|c|c|c|}
\hline No. & Name & $\begin{array}{l}\text { Constructed in } \\
\text { výstavby }\end{array}$ & $1836-1946$ & $1946-1960$ & $1960-2016$ \\
\hline 1 & Kamzičí chalet & & 1 & 1 & 1 \\
\hline 2 & Barborka & 1883 & 1 & 1 & 1 \\
\hline 3 & Ovčárna & 1820 & 1 & 1 & 1 \\
\hline 4 & Maloklínská chalet & & & 1 & 1 \\
\hline 5 & Petrovka & & 1 & 1 & 1 \\
\hline 6 & Měsíční bouda & & 1 & 1 & 1 \\
\hline 7 & Ludvikova bouda & & 1 & 1 & 1 \\
\hline 8 & Josefinka & 1915 & 1 & 1 & 1 \\
\hline 9 & Františkova myslivna & 1865 & 1 & 1 & 1 \\
\hline 10 & Jezerná & 1902 & 1 & 1 & 1 \\
\hline 11 & Dědova chalet & & 1 & 1 & 1 \\
\hline 12 & Bobina & & 1 & 1 & 1 \\
\hline 13 & Kotelská chalet & & 1 & 1 & 1 \\
\hline 14 & Alfrédka & & 1 & 1 & 1 \\
\hline 15 & Kurzovní chalet & 1887 & 1 & 1 & 1 \\
\hline 16 & $\begin{array}{l}\text { Praděd viewing } \\
\text { tower/transmission tower }\end{array}$ & 1912 & 1 & 1 & 1 \\
\hline 17 & Švýcarna & 1829 & 1 & 1 & 1 \\
\hline 18 & Hubertka & & 1 & 1 & 1 \\
\hline 19 & Silonova chalet & & 1 & 1 & 1 \\
\hline 20 & Sabinka & 2002 & 0 & 0 & 1 \\
\hline 21 & Figura & 1994 & 0 & 0 & 1 \\
\hline 22 & Jelení chalet & & 0 & 0 & 1 \\
\hline 23 & Sokolí chalet & & 1 & 1 & 1 \\
\hline 24 & Eustaška & & 1 & 1 & 1 \\
\hline 25 & Hladová chalet & & 1 & 1 & 0 \\
\hline 26 & Jezerní chalet & & 1 & 1 & 0 \\
\hline 27 & Česneková chalet & 1736 & 1 & 1 & 0 \\
\hline 28 & Kamenná chalet & & 1 & 1 & 1 \\
\hline 29 & Zámčisko & & 1 & 1 & 0 \\
\hline 30 & Jelení chalet & & 1 & 1 & 1 \\
\hline 31 & Postal/hikers' chalet & 1940 & 1 & 1 & 1 \\
\hline
\end{tabular}


In 1883, people began reforesting the bare mountaintop areas around Praděd, Malý Děd, and Vysoká hole. Reforestation was carried out under the name of "prize culture". The reforestation activities reflected the appeal made by the Austrian Imperial Association of Foresters on 24 June 1853. Successful works were rewarded with a prize granted by the monarch, hence the name "prize culture" (Hošek, 1973). The plan expected to reforest $3.42 \mathrm{~km}^{2}$. The reforestation activity was stopped in 1907 , with only $1.65 \mathrm{~km}^{2}$ completed. The reforestation was finalized only in the Praděd area, where the original planned area was $0.77 \mathrm{~km}^{2}$. Within that activity, two species of pine were planted, dwarf mountain pine (Pinus mungo) and Swiss pine (Pinus cembra). Altogether 62,680 seedlings of dwarf mountain pine were planted. In the case of Swiss pine, the foresters planted 385,341 seedlings; their production required $612 \mathrm{~kg}$ of seeds. All the seeds came from Alpine countries (Hošek, 1965).

The reforestation seemed successful, and the prevailingly Swiss pine growth grew for 20 to 40 years. After that, however, the pines began to die out in an avalanche manner and disappeared quickly. Only narrow strips of dwarf mountain pine below the peaks of Praděd and Vysoká hole remain till today from this period of reforestation (Hošek, 1972). The strip of the dwarf pine on the southern up to the south-eastern slope of Praděd is located between contour lines at an altitude from 1,390 to $1,400 \mathrm{~m}$ (Fig. 3). This strip of reforested dwarf pine covers an area of 8.5 ha. The non-indigenous dwarf pine and spruce growth might, in the interaction, have both competitive and facilitating elements, depending on the gradient of the local climatic stress. Spruces that are surrounded by dwarf pines have smaller coverage or overlapping of small branches than independent groups of spruces.

\section{Fig. 3: A belt of dwarf mountain pines planted from the beginning of the $20^{\text {th }}$ century on the Praded's southern slope}

Source: private archive

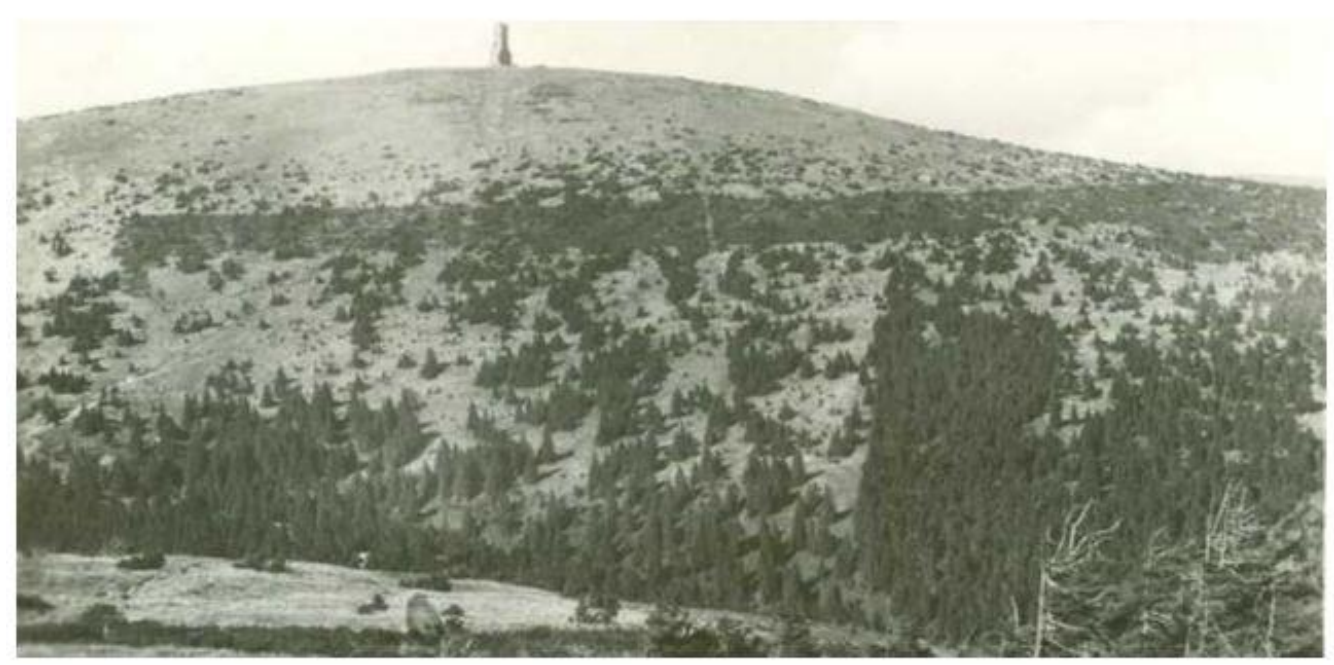


A decline in the grazing of sheep in the Praděd highlands occurred only in the second half of the $19^{\text {th }}$ century. Raising sheep ceased to be profitable in this country, especially because of the competitive cheap imported wool from Australia. Another reason was the finding that grazing in high mountain areas is harmful for the forests, whose economic significance was growing considerably in this period (Hošek, 1973). Starting from the beginning of the $20^{\text {th }}$ century, raising sheep declined in importance. The decline in the profitability of raising sheep was caused by the loss of markets and the low prices of wool, meat, and cheese.

In 1921, the Desensko-Praděd pasture association was established and concentrated its grazing activities in the area of today's Kurzovní chalet. The original building had dimensions of $40 \times 10 \mathrm{~m}$ and provided space for 150 head of cattle. The last time this place was grazed, by approximately 40 head of cattle, was in 1942. Cattle grazing in the Praděd highlands gave way to grazing at the foot of the Hrubý Jeseník and the herds were housed in lower locations, in the newly built premises of united agricultural cooperatives (known as JZD) and state farms.

The last 40 years of the $20^{\text {th }}$ century can be characterized, as a result of the decline of grazing, by the renewal of beech and fir growth (Šamonil \& Vrška, 2007).

After the liberation of the Jeseník area on 5 and 6 May 1945, the expulsion of the local German inhabitants was gradually prepared. This expulsion of the Germans from the entire borderland, as well as the Jeseník, Šumperk, Rýmařov, and Velké Vrbno areas, actually caused the complete displacement of the country and a substantial collapse of agriculture and industry. Towns and villages began to be populated by Czech citizens. However, this resettlement was not complete and some of the houses deteriorated or were demolished or deliberately removed.

The new settlers, however, did not manage to adopt the lifestyle of the displaced German inhabitants. Frequently, the new settlers did not know the specific local methods of farming. On top of this, they were often allocated different land from the original owners of the farms. The new inhabitants began to occupy lower areas, while the higher mountain parts were practically not affected. Afterwards, the era of collectivization took place, during which large state-owned estates and farms were established. This concentration of small farms into big ones was translated into the foundation of large industrial corporations and high-density stables in the hottest regions of the Jeseník mountains. Another impact on the local landscape and its character was caused by the development of company recreation in the mountain areas, individual weekend recreation in the form of chalets, cottages, and weekend country houses, and the construction of new skiing resorts. On 25 July 1969, the Jeseník region was declared the Jeseníky Protected Landscape Area.

\section{Changes in land use on the territory that was monitored}

Development of the upper tree line in the period between 1836 and 2016

In the course of the monitoring period of 180 years, the land use in the area of the Praderd highlands that was monitored saw significant changes. The area was divided into three types of land use: forest, forest-free area, and transitional forest. The forest-free area is to be found in the top parts of the Vysoká hole mountain ridge and in a south-westerly direction to Pec, and also the top of Praděd and a small area on Malý Děd near the Švýcárna chalet (Fig. 4). The transitional forest surrounds the entire forest-free area. The most significant area covered by the transitional forest is the western slope of the Vysoká hole ridge in the south-westerly direction up to Velký Máj and further in the northern part of the territory from Praděd in a north-westerly direction to the Malý Klín mountaintop. Other pronounced areas of the transitional forest can be found in the southern part of the mountain ridge from the top of Pecný in a northerly direction to Pec and further on the eastern slope up to the level of the 
Mackovčin P., Machar I., Brus J, Žáková B.: Changes in the alpine tree line ecotone in the Hrubý Jeseník Mountains (Czech Republic)

Jelení hřbet mountaintop (Fig. 5). The forested area covered $79 \%$ of the territory, the forest-free areas $6 \%$, and the transitional forest $15 \%$ of the territory.

\section{Fig. 4: Švýcárna around 1900 year}

Source: private archive

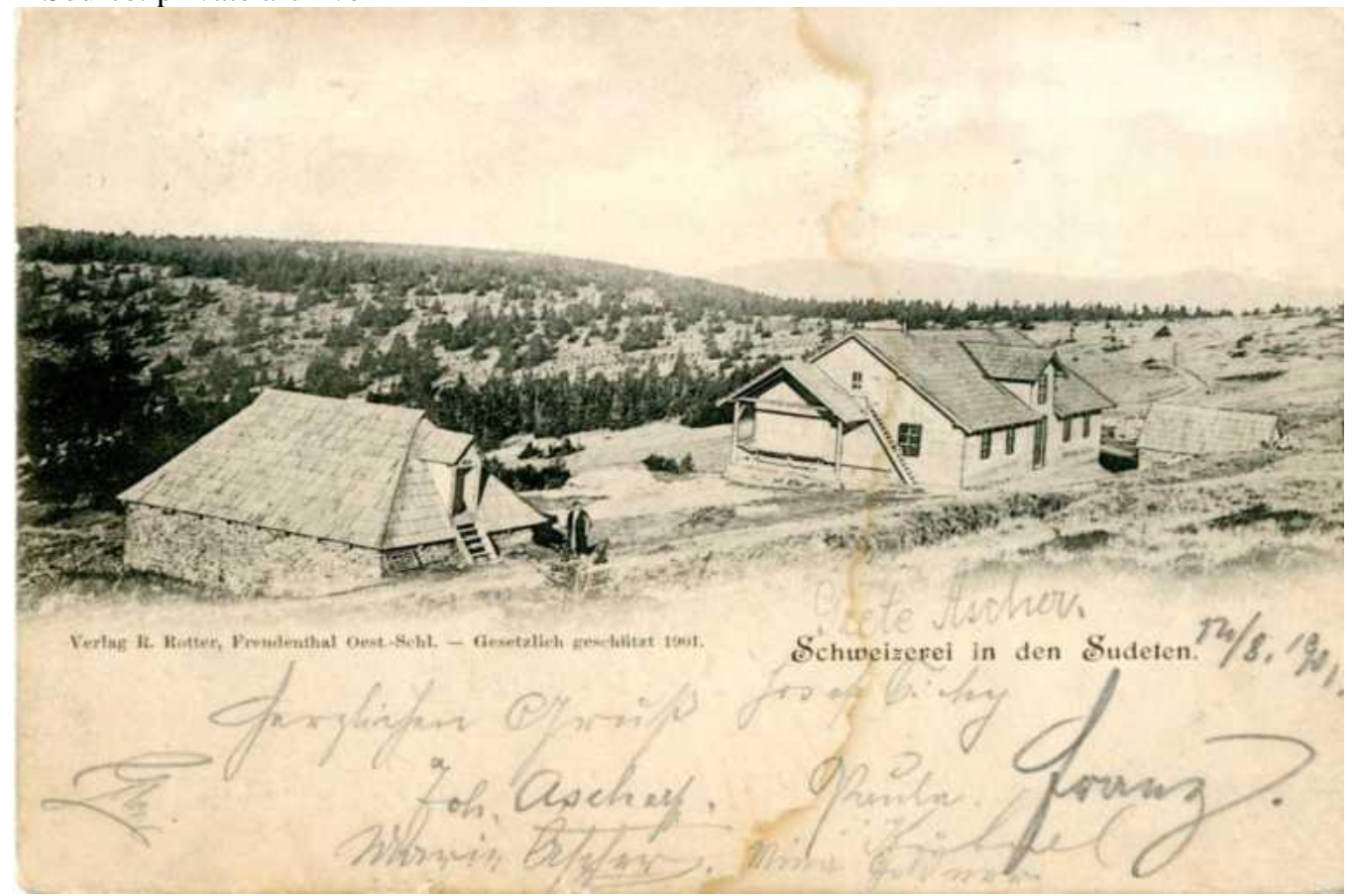


Fig. 5: Land use in a part of the Praděd highlands between 1836 and 2016

Source of data: ČÚZK, VGHMÚř, VÚV T.G.H., and our own elaboration in 2019

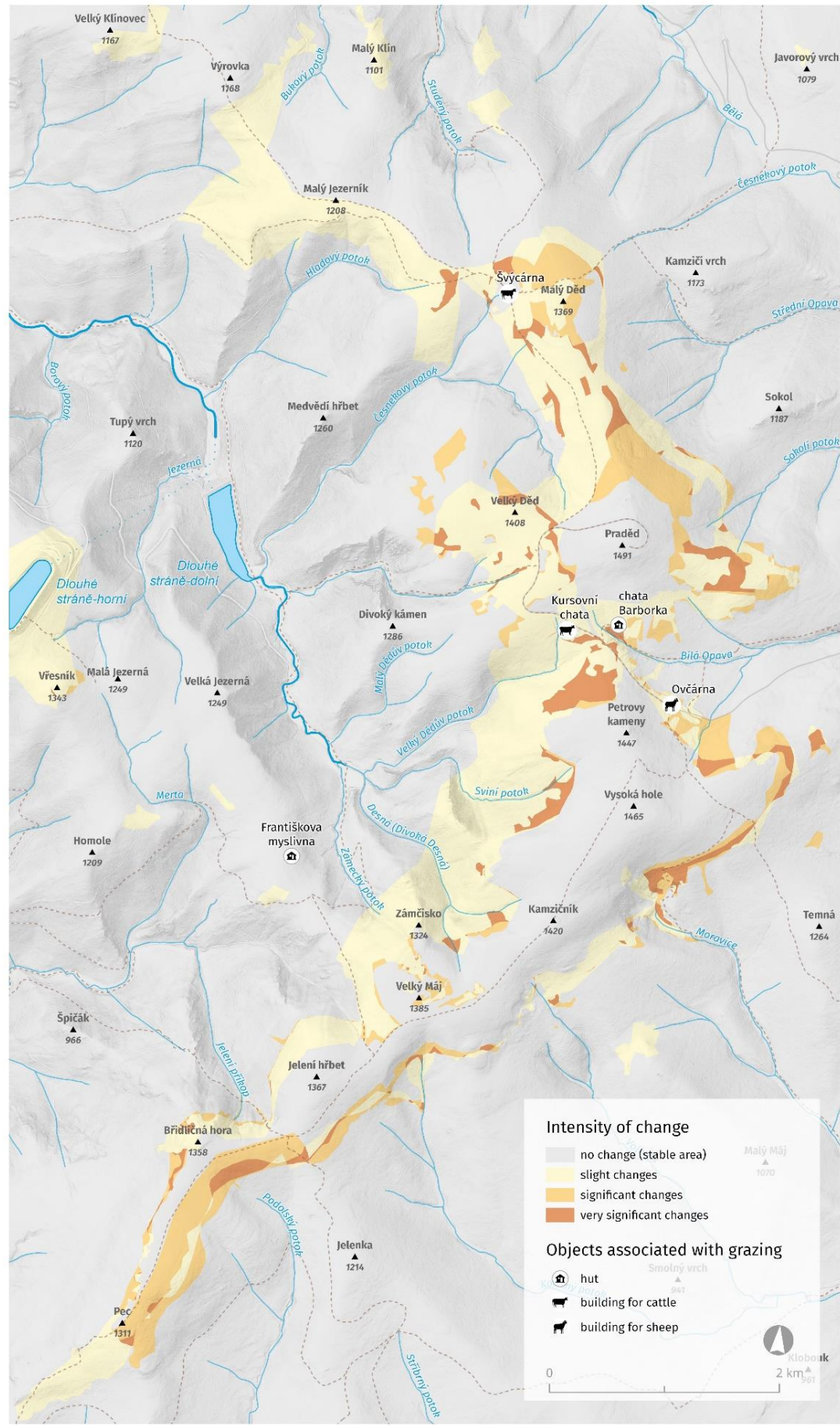


Mackovčin P., Machar I., Brus J, Žáková B.: Changes in the alpine tree line ecotone in the Hrubý Jeseník Mountains (Czech Republic)

\section{Time period between 1836 and 1946}

In the period between 1836 and 1946, the upper tree line moved upwards and vast reforestation of the mountain forest-free area occurred. The reforested area covered $9.89 \mathrm{~km}^{2}$ and the deforested area was $1.04 \mathrm{~km}^{2}$. In 1946, the northernmost place with a mountain forest-free area was the top of Malý Děd. The mountain forest-free areas in a north-westerly direction from Malý Děd were reforested. This covers the area of Malý Klín, as well as the northern part of the mountain ridge leading from Velký Klínovec in a south-easterly direction through Výrovka and Malý Jezerník and further to Malý Děd. Another phase of significant reforestation occurred on the mountain ridge between the Malý Děd and Praděd mountaintops and also on the Praděd western and eastern slopes. On the other hand, a part of the forest west of the Barborka chalet on the southern slope of Praděd was deforested. Further deforestation took place around the Ovčárna chalet. Significant reforestation took place on the western slope of the Vysoká hole ridge south-west of Velký Máj. The western slope of the Jelení hřbet Pecný mountain ridge from Jelení hřbet to Pecný was deforested. On the other hand, the eastern slope was reforested up to the area of the Pec mountaintop.

The comparison follows the map of the stable cadastre for 1836. In that year, forests covered an area of $73.59 \mathrm{~km}^{2}$ and there was a forest-free area of $17.25 \mathrm{~km}^{2}$. In 1946, the comparison follows the topographic map of the Czechoslovak Republic (five-centimetre map). In that year, forests covered an area of $82.45 \mathrm{~km}^{2}$ and the forest-free area was $8.40 \mathrm{~km}^{2}$. Between 1836 and 1946, an area of $1.04 \mathrm{~km}^{2}$ was deforested and $9.89 \mathrm{~km}^{2}$ was reforested (Fig. 10). In that period, the mountain forest-free areas were used, above all, for the grazing of sheep and cattle. In summer the animals were pastured at higher altitudes. Only the following three mountain chalets were used for housing animals: cattle were housed in the Švýcárna and Kurzovní chalets and sheep in the Ovčárna chalet (Fig. 6).

\section{Time period between 1946 and 1960}

In the time period between 1946 and 1960, deforestation clearly prevailed over reforestation. The deforested area was $3.40 \mathrm{~km}^{2}$ and the reforested area was $0.73 \mathrm{~km}^{2}$. Reforestation is obvious on the south-western slope of Malý Děd, on the south-western slope of Praděd, the western slope of Velký Máj, and the western slope of the mountain ridge between Břidličná hora and Pecný. Significant deforestation took place on the mountaintop of Malý Děd and continued further in a south-easterly direction towards Praděd. The northern and western slopes of Praděd were also deforested. Another phase of deforestation took place around the Dědova chalet. In this time period, the upper tree line came down and thus the forest-free area spread in all directions around the Vysoká hole mountaintop. The last area of deforestation took place on the eastern slope of Velký Máj in a south-westerly direction up to Pecný.

The comparison follows the topographic map of the Czechoslovak Republic (five-centimetre map). In 1946, forests covered an area of $82.45 \mathrm{~km}^{2}$ and the forest-free area was $8.40 \mathrm{~km}^{2}$. The comparison for 1960 follows the army topographic map. In that year, forests covered $79.78 \mathrm{~km}^{2}$ and the forest-free area was $11.07 \mathrm{~km}^{2}$. In the time period between 1946 and 1960, an area of $3.40 \mathrm{~km}^{2}$ was deforested and $0.73 \mathrm{~km}^{2}$ was reforested (Fig. 7). This time period is characterized significantly by the expulsion of the Sudeten Germans from the region and the resulting termination of large-area pasture. The mountain chalets that then served as shelters for shepherds and pasture were reconstructed, extended, and adjusted for recreational purposes. 
Fig. 6: Changes in ladn use in a part of the Praděd highlands between 1836 and 1946 Source of data: ČÚZK, VGHMÚř, VÚV T.G.M. and aour own elaboration in 2019

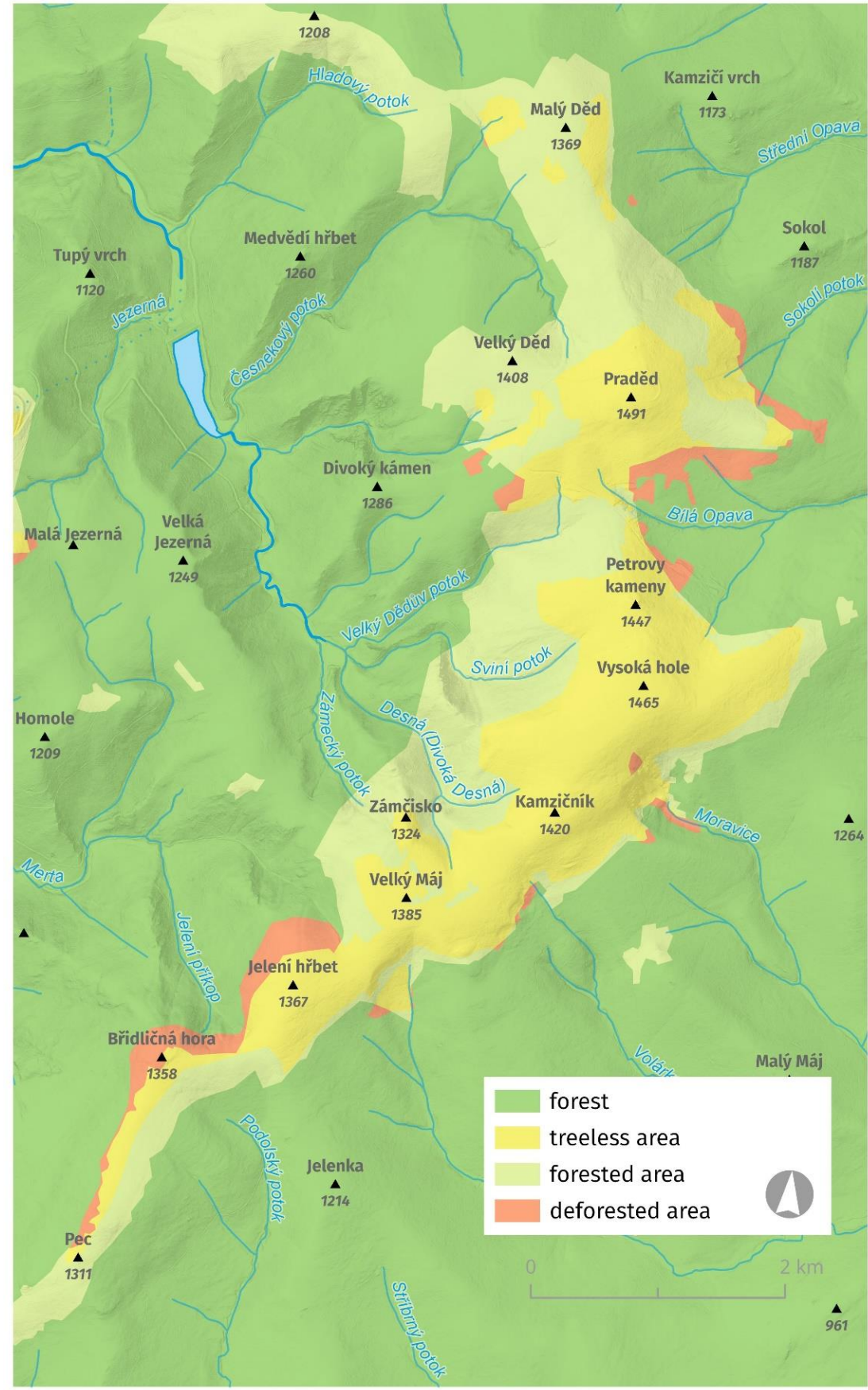


Mackovčin P., Machar I., Brus J, Žáková B.: Changes in the alpine tree line ecotone in the Hrubý Jeseník Mountains (Czech Republic)

Fig. 7: Land use in the territory that was monitores between 1946 and 1960

Source of data: ČÚZK, VGHMÚř, VÚV T.G.M. and aour own elaboration in 2019

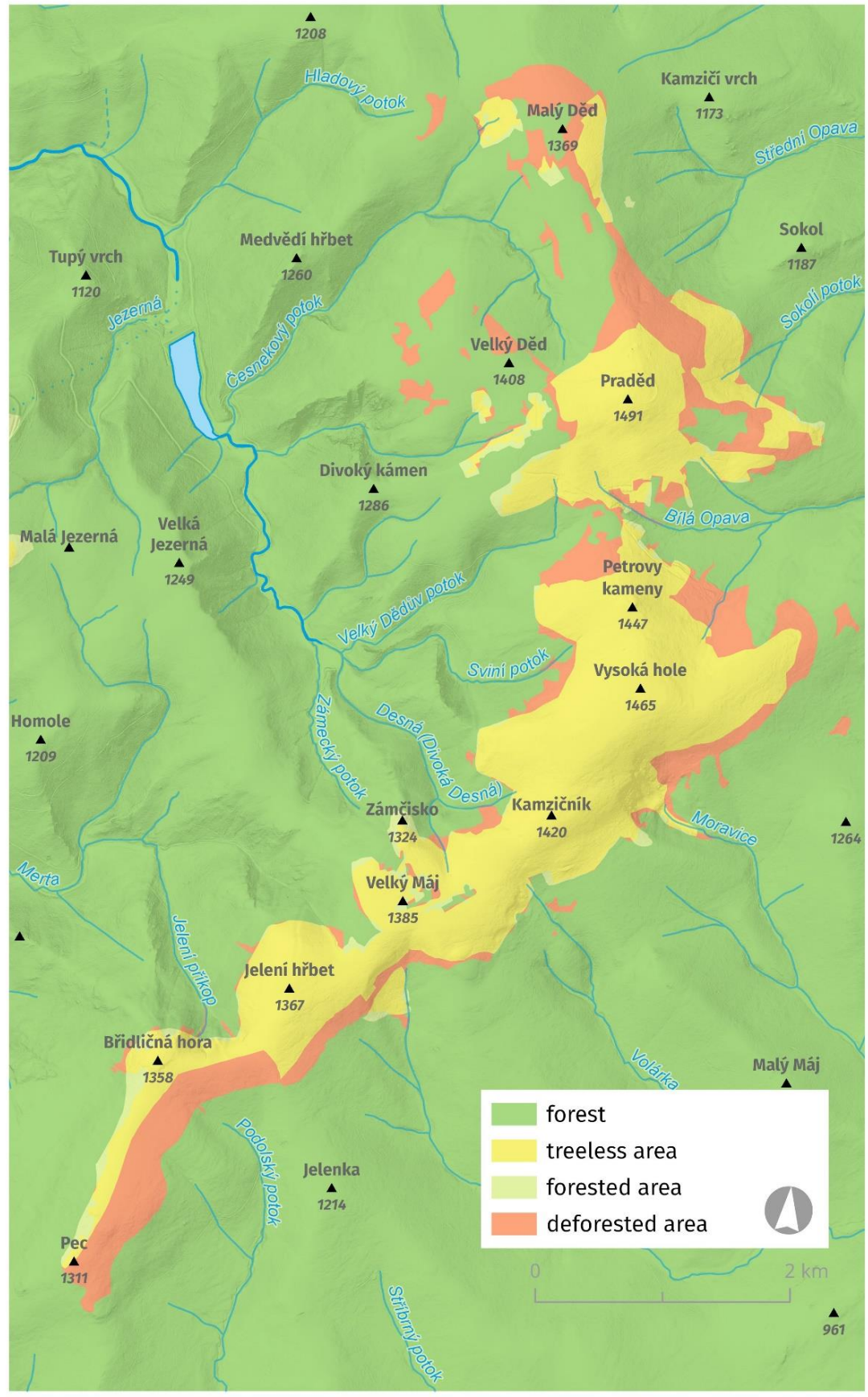


Fig. 8: Land use of the territory that was monitered in the time period between 1960 and 2016

Source of data: ČÚZK, VGHMÚř, VÚV T.G.M. and aour own elaboration in 2019

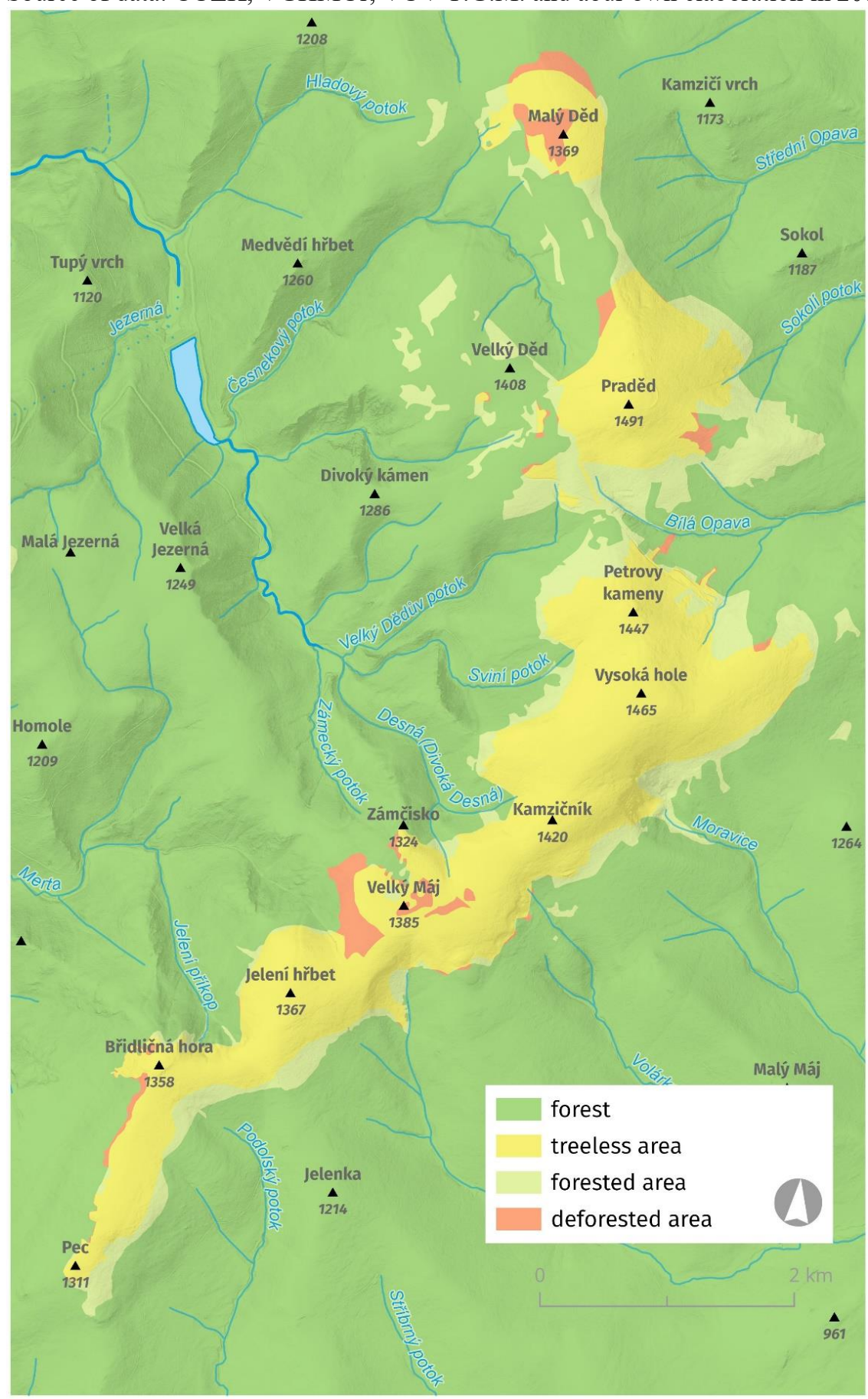


Mackovčin P., Machar I., Brus J, Žáková B.: Changes in the alpine tree line ecotone in the Hrubý Jeseník Mountains (Czech Republic)

\section{Time period between 1960 and 2016}

In the time period between 1960 and 2016, reforestation clearly prevailed over deforestation. The reforested area was $3.23 \mathrm{~km}^{2}$ and the deforested area was $0.57 \mathrm{~km}^{2}$. Most of the deforestation took place in the area of the Malý Děd mountaintop. Other areas affected by deforestation were parts of the south-eastern and north-western Praděd slopes. The valley between Velký Máj and Jelení hřbet was also deforested. On the other hand, the mountain ridge between Malý Děd and Praděd was reforested. Another significant phase of reforestation took place on the south-western, southern, and south-eastern Praděd slopes. The north-western and north-eastern slopes of Vysoká hole were also reforested.

The comparison follows the army topographic map from 1960. In that year, forests covered an area of $79.78 \mathrm{~km}^{2}$ and the forest-free area was $11.07 \mathrm{~km}^{2}$. The comparison for 2016 follows the basic map of the Czech Republic, when forests equalled a value $82.44 \mathrm{~km}^{2}$ and the forest-free area was $8.41 \mathrm{~km}^{2}$ (Fig. 8).

\section{DiSCUSSION AND CONCLUSION}

During the 180 years of the research period, the land use in study area were significantly changed. As time went by, the upper tree line changed and likewise the extent of the Alpine forest-free area. At first, the area was significantly deforested, owing to timber production for iron ore mining and processing. The natural regeneration of the mountain forest was limited by sheep and cattle grazing. Later, planning for reforestation occurred. The results stated in this study may be partially compared with those of Treml and Banaš's study (2000), the authors of which used the method of panchromatic imagery from aerial images in order to define the Alpine tree line. They measured the current area of the Alpine forest-free areas around Malý Děd, Praděd, and Vysoká hole to be $9.72 \mathrm{~km}^{2}$ and the total area of the Alpine forest-free area is, according to these authors, $0.76 \mathrm{~km}^{2}$ larger than that shown in our results. This difference may be caused by the differences in the methodology used for defining the Alpine forest-free area (Rejmánek et al., 1971).

On the evidence of our results, the area of the Alpine forest-free area was at its largest in 1846 (it was $17.25 \mathrm{~km}^{2}$ according to the stable cadastre map). This was influenced by the fact that the top parts of the Praděd highlands were intensely used both for sheep and cattle grazing and timber production. Timber production was, in that period, carried out in the form of clear cutting, which reached up to the upper tree line. On the contrary, in 1946 the forest-free area was the smallest $\left(8.40 \mathrm{~km}^{2}\right)$, possibly also as a result of anthropogenic activities being suppressed in the territory that was monitored during the Second World War and also in relation to the forced expulsion of the Sudeten Germans from the entire region of the Jeseníky mountains. In 1960, the Alpine forest-free area increased $\left(11.07 \mathrm{~km}^{2}\right)$, possibly in relation to the development of the intense utilization of the region mainly for recreational purposes (the chalets that were originally for shepherds and hunters were changed into sizable recreational properties).

Only three mountain ranges in the Czech Republic reach above the upper tree line - the Krkonoše (the Giant Mountains), Hrubý Jeseník, and Králický Sněžník (Jeník, 1961). In the Krkonoše, only certain sub-parts, formed prevailingly by crystalline rock, can, from the geomorphological point of view, be classified as the sub-Alpine level. The first of them is the Krkonoše ridges culminating in the four highest mountaintops of the Czech Republic (Sněžka, 1,602.3 mamsl, Luční hora, 1,555.3 mamsl, Studniční hora, 1,554.4 mamsl, and Vysoké Kolo, 1,508.5 mamsl). The second of them is the Krkonoše forks, following the valleys of welling streams and the first tributaries of the Elbe and Úpa. 
Climatic conditions in the high areas of the Krkonoše inhibited the possibility of high-forest growth, which results in a relatively short vegetation period because of the low temperatures. That is why the spruces around the upper tree line are low and deformed by climatic factors (by wind, snow, and frost). To a certain extent, they resemble bushes. They individually penetrate the growth of dwarf pine - bushy mountain dwarf pine (Pinus mugo). At altitudes between 1,250 and 1,500 mamsl the dwarf pine forms growth with a more or less closed canopy. The dwarf pine reaches Krkonoše the northernmost location of its spread in the Krkonoše. In peat bogs, the dwarf pines form what is known as special 'table' forms. It is difficult to determine the absolute age of the dwarf pines. The oldest branches to be studied were, according to year rings, over 320 years old but, with respect to the fact that decumbent branches of the species enroot easily, the original old part of the polycormon may die out and disappear. On the contrary, younger branches survive at the edge of the dwarf pine or it may even become the basis for a 'new' polycormon. The dwarf pine thus spreads easily in a vegetative way. Reproduction through seeds is not as common as the herbaceous vegetation does not provide enough opportunities for their germination. The vegetation below the dwarf pine differs significantly from the local grassland communities as the intense shade, thick layer of undecomposed needles, and relatively very acid soil reactions create similar conditions to mountain pine forests (Šebková et al., 2011).

That is the reason why the dwarf pine is accompanied by species of plants typical for the spruce level, such as Homogyne alpina, Trientalis europaea, Rhodococcumvitis-idaea, Vaccinium myrtillus, Avenella flexuosa, and Calamagrostis villosa. The shade below the dwarf pine provides good conditions for the cloudberry (Rubus chamaemorus), which grows here in its standard size. The dwarf pine growth also provides a home for several species of insects. The caterpillars of Dendrolimus pini and Neodiprion sertifer feed on the pine needles. The basis of pine needles provides feed for the larvae of a little fly, Thecodiplosis brachyntera. The needles that are affected turn yellow and fall at the end of their development in August or September. In the bark of, especially damaged, branches, there live the six-toothed bark beetle - Pityogenes chalcographus - which is rather well known as a spruce pest, and Pityogenes conjunctus.

In the Alpine zone of the Krkonoše, the dwarf pine growth alternates with sub-Alpine meadows and peat bogs. Towards the mountaintops, the dwarf pine growth becomes thinner and changes into what is known as Alpine grassland. These areas are characterized by low air temperatures (annual average $0-1{ }^{\circ} \mathrm{C}$, July temperatures just over $8{ }^{\circ} \mathrm{C}$, and the daily temperature average does not exceed $0{ }^{\circ} \mathrm{C}$ for six months of the year).

During the $17^{\text {th }}$ century, people started to make hay in the area of the upper tree line of the Krkonoše ridges and forks and above it, and later on, they used the land for pasture. This led to the construction of the first settlements on the Krkonoše ridges. This was the beginning of what was called the cabin economy, which, as the landlords soon realised, meant good opportunities for the economic improvement of mountain estates. The first cabins in the dwarf pine zone were already founded in the first half of the $17^{\text {th }}$ century. The dwarf pines growing in the vicinity of these cabins had to be cut down and gave way to grassland and pastures. The enclaves around the mountain ridge cabins significantly lowered the upper tree line, specifically from 1,250 m to even down to 1,000 mamsl at times. At the beginning of the $19^{\text {th }}$ century, there were altogether 1,621 cabins on the territories of selected Krkonoše land estates, especially on the Jilemnice, Vrchlabí, and Maršíkov land estates. If we add the cabins from the Silesian part (then Prussia) and the Žaclér̆ land estates, we come to the astonishing figure of 2,500 cabins. The number of grazing animals amounted to approximately 20,000 head of cattle, 10,000 goats, and lower numbers of sheep and horses. 
Mackovčin P., Machar I., Brus J, Žáková B.: Changes in the alpine tree line ecotone in the Hrubý Jeseník Mountains (Czech Republic)

Králický Sněžník is a rugged highland, a massif formed by the gneiss of Orlice-Kladsko crystalline complex and limited in the western part by the Kladsko shift (Demek \& Mackovčin, 2006). The primary forest-free area in the region is formed, above all, by sub-Alpine vegetation spreading only in the highest parts of Králický Sněžník $(1,423.7$ mamsl). This is a complex of many communities above the upper tree line which boasts species diversity. In the depressions in the terrain, marsh alderwoods grow on waterlogged soils (Alnion glutinosae) with tall sedges, Humulus lupulus, Iris pseudacorus, Solanum dulcamara, and, at times, with the rarer species Cicuta virosa and Ranunculus lingua. Alderwoods with the following species also find their home here - alderwoods with Carici elongatae- Alnetum, alderwoods with Calamagrostio canescentis-Alnetum and alderwoods with Carici acutiformis-Alnetum) (Krahulec, 1975).

The geomophological unit of the Hrubý Jeseník, with its highest Moravian mountain, Praděd (1,491.3 mamsl), is an extensive mountain range. It is divided into three unequally elevated and erosion-rugged massifs or sub-units: the Praděd, Keprník, and Medvěd highlands. The geological structure of the Hrubý Jeseník is very complex, comprising a wide range of metamorphic rock types which form Hercynian orogeny construction. In restricting the massifs, tectonic disorders occur in the NW-SE and NNE-SSW directions. They are reflected in the presence of pronounced and deep mountain saddles (among others the following mountain saddles: Červenohorské sedlo, Ramzovské sedlo, and Videlské sedlo). In the highest parts of the Hrubý Jeseník and Králický Sněžník, the upper (Alpine) tree line, runs at an altitude of approximately between 1,300 and 1,350 mamsl where the sub-Alpine and Alpine vegetation comes into contact with the spruce woods (Vahalik \& Mikita, 2011).

The dwarf pine growths (corresponding with Myrtillo-Pinetummughi, Pinionmughi) are, however, non-indigenous in the Hrubý Jeseník as well as Králický Sněžník; they come from widespread planting that already commenced in the mid- $19^{\text {th }}$ century. Bushy growths (Salicion silesiaceae) inhabit the steeper slopes of avalanche tracks in the area of the upper tree line. Betula carpatica and Salix silesiaca are typical species. These communities are to be found only in the top parts of the Hrubý Jeseník in the Praděd national reserve, especially in the Velká and Malá kotlina folds (Simon et al., 2014).

From the botanical point of view, the Alpine forest-free area is to be found in three locations in the Czech Republic: the Krkonoše, Králický Sněžník, and the Hrubý Jeseník (Soukupová et al., 1995).

The upper tree line in the Hrubý Jeseník and Králický Sněžník has several common features and differs significantly from the upper tree line in the Krkonoše. A significant difference in the upper tree line lies in the herbaceous cover. The dwarf pine growth is non-indigenous in the Hrubý Jeseník and Králický Sněžník. In the Krkonoše, the trees at the upper tree line are, on average, taller and with larger differences in height, which might be caused by a higher degree of planting spruces at the upper tree line (Treml \& Banaš, 2000).

In the Hrubý Jeseník, the Alpine forest-free areas lie in seven regions and their total area amounts to 1,103 ha. The maximum upper tree line in the Czech Republic reaches its highest altitude in the Hrubý Jeseník, namely on the western slopes of Praděd, up to an altitude of 1,430 mamsl. In Králický Sněžník, the forest-free area is the smallest and reaches the extent of 65 ha. The forest-free area in the Krkonoše is, with its extent amounting to 5,465 ha, the largest in the Czech Republic (Table 2). 
Table 2: Basic characteristics of the upper tree line in the Czech Republic

Source: Krahulec, 1975

\begin{tabular}{|l|c|c|c|}
\hline Mountain range & Krkonoše & Králický Sněžník & Hrubý Jeseník \\
\hline $\begin{array}{l}\text { Average altitude of the upper } \\
\text { tree line (m) }\end{array}$ & 1,230 & 1,305 & 1,302 \\
\hline $\begin{array}{l}\text { Total area of the current Alpine } \\
\text { forest-free area (estimate) (ha) }\end{array}$ & 5,465 & 65 & 1,103 \\
\hline
\end{tabular}

Understanding the historical development of the Alpine tree line is of great importance for the future sustainable management of mountain ecosystems (Svoboda et al., 2012). Our study of the historical land use in the Hrubý Jeseník Mountains supports the effort to maintain these unique ecosystems (Andreska, 2012). These findings can also be important for better knowledge of reconstructing the history of grazing in Europe in the past. Currently, the historical influence of grazing on the alpine tree line in the Hrubý Jeseník Mountains is being enhanced by downhill skiing (Hedl et al., 2012).

\section{ACKNOWLEDGEMENT}

This paper was supported by the "Forgotten history of the mountain forests of the Hrubý Jeseník" project no. DG18P02OVV061 within the NAKI II programme of the Ministry of Culture of the Czech Republic.

\section{CONFLICTS OF INTEREST}

The authors declare no conflict of interest.

\section{REFERENCES}

Andreska, J., (2012). Historie lesů a lesního hospodaření v ČR (Forest history in the Czech Republic). In: Machar I, Drobilová L, Ochrana př́rody a krajiny v České republice, vol. I: (pp. 232-234).

Bednář, V., (1958). Příspěvek k poznání společenstev holí Hrubého Jeseníku (Contribution to knowledge of plant Alpine grassland communities in Hruby Jesenik Mountains). Sbornik Vysoké školy pedagogické, Př́rodní Vědy, Olomouc, 5: 125-150.

Bednář, V., (1960). Rostlinná společenstva Břidličné v Hrubém Jeseníku (Plant Alpine grassland communities in Hruby Jesenik Mountains). Acta Univ. Palack. Olom., Fac. Rer. Natur., Olomouc, 5: 5-16.

Bohn, U., Neuhäusl, R., Gollub, G., Hettwer, C., Neuhäuslová, Z., Schlüter, H., Weber, H., (2002). Map of the Natural Vegetation of Europe. Scale 1:2 500 000. Landwirtschaftsverlag, Münster.

Bureš, L. et al., (2008). Analýza antropických vlivư v nejcennějších částech CHKO Jeseníky: závěrečná zpráva za obdobi 2004-2008 (Analyses of anthropogenic impacts on valuable parts of Jeseniky Protected Landscape Area). Agentura ochrany př́rody a krajiny ČR. Praha. Bureš, L., Burešová, Z., (1989). Geobotanická expertiza k provádění experimentální 
Mackovčin P., Machar I., Brus J, Žáková B.: Changes in the alpine tree line ecotone in the Hrubý Jeseník Mountains (Czech Republic)

likvidace kleče v SPR Malá kotlina plant Alpine grassland communities in Hruby Jesenik Mountains (Geobotanical study of experimental clear-cutting on dwarf pine in Mala Kotlina Nature Reserve). Manuskript, Správa CHKO Jeseníky, KSPPOP Ostrava.

Bureš, L., Králík, J., (1977). Synantropní flóra nejvyšších poloh Hrubého Jeseníku (Flora in the high localities of Hruby Jesenik Mountains). Časopis Slezského Muzea Ser. A, 26: 167-175.

Bureš, L., Kočvara, R., Kuras, T., Hradecký, J., (2005). Problematika kleče v Hrubém Jeseniku (Dwarf pine in Hruby Jesenik Mountains). Manuskript, Správa CHKO Jeseníky, Ekoservis, $36 \mathrm{~s}$.

Chytrý, M., Kučera, T., Kočí, M., Grulich, V., Lustyk, P., (2010). Habitat Catalogue of the Czech Republic. Agency of Nature Conservation and Landscape Procetion, Prague. 445 pp.

Demek, J., Mackovčin, J., (2006). Hory a nižiny (Mountains and lowlands). Agentura ochrany prŕrody a krajiny ČR, Prague, $580 \mathrm{pp}$.

Hedl, R., Houska, J., Banas, M., Zeidler, M. (2012). Effects of skiing and slope gradient on topsoil properties in an Alpine environment. Polish Journal of Ecology, 60 (3): 491-501.

Garamvoelgyi, A., Hufnagel, L., (2013). Impacts $f$ climate change on vegetation distribution no.1. Climate change induced vegetation shifts in the Palearctic region. Applied Ecology and Environmental Research, 11(1): 79-122.

Hejcman, M., Češková, M., Hejcmanová, P., Pavlů, V., Jones, M., (2010). Expansion of Calamagrostis villosa in sub-alpine Nardus stricta grassland: Cessation of cutting management or high nitrogen deposition? Agriculture Ecosystems \& Environment, 129: 91-96.

Hejcman, M., Dvořák, I., Kociánová, M., Pavlů, V., Nežerková, P., Vítek, O., Rauch, O., Jeník, J., (2006). Snow depth and vegetation pattern in a late-melting snowbed analyzed by GPS and GIS in the Giant Mountains, Czech Republic. Arctic, Antarctic and Alpine Research, 38: 90-98.

Honnay, O., Verheyen, K., Bossuyt, B., Hermy, M., (2004). Forest Biodiversity: Lessons from history to conservation. CABI Publishing, Wallingford. $358 \mathrm{pp}$.

Hošek, E., (1965). Historický pri̊zkum pro Lesní hospodáršḱ celek Loučná (Historical research in the frame of Forest Management Plan Loučná). Ústav hospodářské úpravy lesů, pobočka Olomouc. Work document for internal use.

Hošek, E., (1970). K otázce vývoje škod abiotickými vlivy v lesích Hrubého Jesníku (The problems of abiotic factors impacts on forests In the Hruby Jesenik Mountains). Campanula, 1970(1): 13-21.

Hošek, E., (1964). Zalesňování horských holí na Králickém Sněžníku a Keprníku kolem r.1900 (Reforestation of alpine grasslands in Kralicky Sneznik and Keprnik mountains). Časopis Slezského Muzea (C), 3: 65-73.

Hošek, E., (1972). Dosavadní vývoj horní hranice lesa v Jeseníkách (Current development of tree-line in Jeseniky Mountains). Ochrana přirody, 27: 101-113.

Hošek, E., (1973). Vývoj dosavadního hospodaření v nejvyšších polohách Jeseníků a jeho vliv na horní hranici lesa (History of forest management in the Hruby Jesenik Mountains). Campanula, 4: 69-81.

Jeník, J., (1961). Alpine grasslands of the Giant Mountains, Kralicky Sneznik Mountains and Jeseniky Mountains. Academy of Science, Prague. 132 pp. 
Jeník, J., Lokvenc. T., (1962). Die alpine Waldgrenze im Krkonoše Gebirge. Rozpravy Čs Akademie věd Praha, ser. Math. - natur., 72(1): 1-65.

Jeriová, J., (1970). Fytocenologická studie Velké Kotliny v Hrubém Jeseníku (Phytocoenological study of Velka Kotlina locality in Hruby Jesenik Mountains). Master thesis. Palacky Univerzity, Olomouc.

Knappe, J.V., (1803). Lesní hospodářský plán panství Bruntál pro obdobi 1803-1813 (Forest management plan for Bruntál estate in 1803-1813). Státní oblastní archiv Opava, signatura 1.391. Nepublikovaný archivní dokument.

Kolström, T., (1998). Ecological simulation model for studying diversity of stand structure in boreal forests. Ecological Modelling 111: 17-36.European beech-dominated natural stands effects of scale. Forest Ecology and Management, 328: 353-364.

Krahulec, F. (1975). Vegetace kulminační části Králického Sněžníku (Vegetation of Kralicky Sneznik Mountains. Master thesis. Katedra botaniky PřF UK Praha.

Křrižek M., Treml V., Engel Z., (2005). Periglaciální tvary Hrubého Jeseníku z hlediska jejich aktivity (Periglacial in Hruby Jesenik Mountains). In: Sborník referátí z konference $k 35$. výroči CHKO Jeseníky (pp. 9-15), Správa CHKO Jeseník, 1. vydání, Jeseník: CHKO Jeseníky.

Křrižek M., Treml V., Engel Z., (2008). Prostorové rozšíření periglaciálních tvarů alpinského bezlesí Vysokých Sudet (Periglacial in alpine grasslands of Vysoke Sudety Mountains). In: Traczyk, A. ed.: Geomorfologia Sudetów stan badań i perspektywy (pp. 29 - 30), Zakład Geomorfologii - Instytut Geografii i Rozwoju Regionalnego, Wrocław: Uniwersytet Wrocławski.

Křŕžek, M., Krause, D., Uxa, T., Engel, Z., Treml, V., Traczyk, A., (2019). Patterned ground above the alpine timberline in the High Sudetes, Central Europe. Journal of Maps, 15(2): 563-569.

Macků, J., (2014). Climatic characteristics of forest vegetation zones of the Czech Republic. Journal of Landscape Ecology, 7(3): 39-48.

Maděra P., Buček A., Culek M., Friedl M., Kirchner K., Pechácek J., Roštínský P., Sedlácek A., Šenfeldr M., Špinlerová Z., Štykar J., Tippner A., Vavrícek D., (2011). Geobiocenózy horni hranice lesa a vliv porostu borovice klece na horskou krajinu v Hrubém Jeseníku a rizika, spojená s jejich odstranéním (Geobiocoenoses in the alpine tree line including dwarf pine management and related environmental risks in the Hruby Jesenik Mountains), Záverecná zpráva výzkumného projektu Grantové služby LCR. Brno: LDF MENDELU a Lesy CR s. p. 215 s.

Micklitz, J., (1857). Die forstlichen Vegetations- Verhältnisse Altvater Gebirges. Abgedruckt aus den Verhandlungen der Forst-Sektion für Mähren und Schlesien, Brunn. 117 Seiten.

Musil, I., (2010). Jesenické horské hole, horní hranice lesa a kosodřevina (Alpine grasslands, tree line and dwarf pine). Lesnická práce, 89(7): 25-27.

Neuhäusl, R., Neuhäuslová-Novotná, Z., (1966). Výškové rozšíření fytocenotických a stanovištních indikátorů na území Hrubého Jeseníku a Králického Sněžníku (Altitudinal distribution of habitat factors in the Hruby Jesenik and Kralicky Sneznik Mountains). Časopis Slezského Muzea Ser. A., 15: 29-43.

Nozicka, J, (1957). Přehled vývoje našich lesů (Forest history in our country). SZN, Prague. 246 pp.

Novák, J., Petr, L., \& Treml, V., (2010). Late-Holocene human-induced changes to the extent 
Mackovčin P., Machar I., Brus J, Žáková B.: Changes in the alpine tree line ecotone in the Hrubý Jeseník Mountains (Czech Republic)

of alpine areas in the East Sudetes, Central Europe. The Holocene, 20(6), 895-905.

Rejmánek, M., Sýkora, T., Štursa, J., (1971). Fytocenologické poznámky k vegetaci Hrubého Jeseníku (Notes to vegetation in the Hruby Jesenik Mountains). Campanula, 2: 31-39.

Šamonil, P., Vrška, T., (2007). Trends and cyclical changes in natural fir-beech forests at the north-western edge of the Carpathians. Folia Geobotanica, 42: 337-361.

Simon, J., Machar, I., Buček, A., (2014). Linking the historical research with the growth simulation model of hardwood floodplain forests. Polish Journal of Ecology, 62: 375-359.

Skaloš, J., Weber, M., Lipsky, Z., Trpakova, I., Santruckova, M., Uhlirova, L., Kukla, P., (2010). Using old military survey maps and orthophotograph maps to analyse long-term land cover changes - case study (Czech Republic). Applied Geography, 31: 426-438.

Svoboda, M. Janda, P., Nagel, T.A., Fraver, S., Rejzek, J., Bace, R., (2012). Disturbance history of an old-growth sub-alpine Picea abies stand in the Bohemian Forest, Czech Republic. Journal of Vegetation Science, 23 (1): 86-97.

Sokol, F., (1965). Vliv přrrodního prostředí a lidské činnosti na vznik svahových sesuvi̊ a dosavadní zkušenosti s jejich rekultivací v Hrubém Jeseniku (Impacts of both natural factors and human activities on slope erosion in the Hruby Jesenik Mountains). Dissertation thesis MZLU Brno.

Soukupová L., Kociánová M., Jeník J., Sekyra J., (1995). Arctic-alpine tundra in the Krkonoše, the Sudetes. Opera Corcontica, 32: 5-88.

Šebková, B., Šamonil, P., Janík, D., Adam, D., Král, K., Vrška, T., Hort, L., Unar, P., (2011). Spatial and volume patterns of an unmanaged submontane mixed forest in Central Europe: 160 years of spontaneous dynamics. Forest Ecology and Management, 262: 873-885.

Šenfelder, M., Maděra, P., (2011). Population Structure and Reproductive strategy of Norway spruce (Picea abies L. Karst) above the Former Pastoral Timberline in the Hruby Jesenik Mountains, Czech Republic. Mountain Research and Development, 31(2): 131-143.

Šenfelder, M., Treml, V., Maděra, P., Volařík, D., (2014). Effects of Prostrate Dwarf Pine on Norway Spruce Clonal Groups in the Treeline Ecotone of the Hruby Jesenik Mountains, Czech Republic. Arctic, Antarctic, and Apline Rerearch, 46(2): 430-440.

Šenfeldr, M., Urban, J., Maděra, P., \& Kučera, J., (2016). Redistribution of water via layering branches between connected parent and daughter trees in Norway spruce clonal groups. Trees, 30(1): 5-17.

Šenfeldr, M., \& Treml, V., (2020). Which generative reproduction characteristics determine successful establishment of the subalpine shrub Pinus mugo? Journal of Vegetation Science, 31(3): 403-415.

Švajda, J., (2008). Climate change and timber line in the European Mountains - Current knowledge and perspectives. Oecologia Montana, 17: 30-33.

Treml, V., Banaš, M., (2000). Alpine timberline in the High Sudetes. Acta Universitatis Carolinae Geographica, 15: 83-99.

Treml, V., Křížek, M., (2006). Vliv borovice kleče (Pinus mugo) na strukturní půdy české části Východních Sudet (Impacts of dwarf pine on soil structure in the Vychodni Sudety Mountains). Opera Corcontica. 43: 45-56.

Treml, V. (2007). The effect of terrain morphology and geomorphic processes on the position and dynamics of the alpine timberline. In: Kalvoda, J. and Goudie, A.D. (eds.): Geomorphologic variations. A case study from the High Sudetes, Czech Republic (120 pp.) 
ProGrafisPub, Praha

Treml, V., Šenfeldr, M., Chuman, T., Ponocná, T., Demková, K. (2016). Twentieth century treeline ecotone advance in the Sudetes Mountains (Central Europe) was induced by agricultural land abandonment rather than climate change. Journal of Vegetation Science, 27(6): 1209-1221.

Vahalik, P., Mikita, T., (2011). Possibilities of forest altidudinal vegetation zones modelling by geoinformatic analysis. Journal of Landscape Ecology, 4(2): 49-61.

Wild, J., Wildová, R., (2002). Interactions between dwarf pine shrubs and grassland vegetation under different management. Opera Corcontica, 39: 17-34.

Wild, J., Winkler, E., (2008). Krummholz and grassland coexistence above the forestline in the Krkonoše Mountains: Grid-based model of shrub dynamics. Ecological Modelling, 213: 293-307.

Zeidler, M., Banaš, M., Duchoslav, M., Lešková, M., (2010). Vliv vysazených klečových porostů na alpínskou vegetaci v Hrubém Jeseníku (Impacts of dwarf pine stands on alpine vegetation in the Hruby Jesenik Mountains). Príroda, 29: 37-50. 